
FIT(1)PATOLOGI
INDONESIA
Volume 13, Nomor 5, September 2017
Halaman 175-183
ISSN: 0215-7950
DOI: $10.14692 /$ jif.13.5.175

\title{
Identifikasi Colletotrichum spp. Asal Tanaman Pepaya
}

\section{Identification of Colletotrichum spp. Originated from Papaya Plant}

\author{
Eryna Elfasari Rangkuti, Suryo Wiyono, Widodo* \\ Institut Pertanian Bogor, Bogor 16680
}

\begin{abstract}
ABSTRAK
Colletotrichum spp. sebagai penyebab penyakit antraknosa merupakan salah satu faktor pembatas produksi pepaya (Carica papaya). Tujuan penelitian ini ialah mengidentifikasi spesies Colletotrichum spp. dari berbagai bagian tanaman pepaya yang menunjukkan gejala antraknosa. Sebanyak 20 galur Colletotrichum spp. berhasil diisolasi, selanjutnya dilakukan pengelompokkan menjadi 3 tipe morfologi berdasarkan kemiripan koloni dan bentuk konidia. Sebanyak 12 galur dari kelompok I dan 3 galur dari kelompok II diidentifikasi sebagai C. gloeosporioides sensu lato berdasarkan morfologi koloni dan bentuk konidia silinder yang kedua ujungnya membulat. Sementara itu 1 galur dari kelompok II secara molekuler diidentifikasi sebagai C. magnum. Empat galur dari kelompok III dengan bentuk konidia melengkung dan berujung runcing, serta membentuk setae pada medium buatan diidentifikasi secara molekuler sebagai C. truncatum. C. gloeosporioides ditemukan pada batang, tangkai daun, dan buah. C. magnum dan C. truncatum masing-masing ditemukan pada tangkai daun dan buah. Selain karakter morfologi dan molekuler, perbedaan respons pertumbuhan koloni terhadap suhu dapat digunakan untuk mengonfirmasi spesies Colletotrichum tersebut. Keberadaan Colletotrichum yang menginfeksi pada bagian batang dan tangkai daun pepaya di pertanaman dan temuan spesies C. magnum dan C. truncatum pada tanaman ini merupakan laporan pertama di Indonesia.
\end{abstract}

Kata kunci: C. gloeosporioides, C. magnum, C. truncatum, morfologi, molekuler

\begin{abstract}
Colletotrichum spp. is known as the causal agent of anthracnose and considered as an important limiting factors on papaya production. The objective of this study was to determine the species of Colletotrichum spp. from various plant parts of papaya (Carica papaya) showing anthracnose symptom. Twenty isolates of Colletotrichum spp. was isolated and were grouped into 3 morphological groups based on colony similarity, conidial morphology, and setae formation. A total of 12 isolates of group I and 3 isolates of group II were identified morphologically as $C$. gloeosporioides sensu lato based on cylindrical conidia with rounded on both ends and colony morphology. Meanwhile, 1 isolate of group II was molecularly identified as C. magnum. Four isolates of group III with a curved and pointedend conidia, and produced setae on artificial medium were identified molecularly as $C$. truncatum. $C$. gloeosporioides was obtained on stem, leaf petiole, and fruit. C. magnum and C. truncatum were only obtained on leaf petiole and fruit, respectively. In addition to morphological and molecular characters, differences in colony growth responses to temperature can be used to distinguish the species of Colletotrichum. To our knowledge the existence of anthracnose symptom on the stems and leaf petioles of papaya in the fields and the discovery of C. magnum and C. truncatum isolated from papaya was the first report in Indonesia.
\end{abstract}

Key words: C. gloeosporioides, C.magnum, C. truncatum, molecular, morphology

*Alamat penulis korespondensi: Departemen Proteksi Tanaman, Fakultas Pertanian, Institut Pertanian Bogor, Jalan Kamper, Kampus IPB Darmaga, Bogor 16680

Tel: 0251-8629364, Faks: 0251-8629362, Surel: widodo@apps.ipb.ac.id 


\section{PENDAHULUAN}

Pepaya (Carica papaya) merupakan salah satu buah yang banyak dikonsumsi di Indonesia. Salah satu faktor pembatas dalam peningkatan produksi, baik kualitas maupun kuantitas buah pepaya ialah infeksi Colletotrichum sp. penyebab antraknosa ketika buah masih di pertanaman maupun saat pascapanen.

Pada umumnya antraknosa pada pepaya lebih dikenal sebagai penyakit pascapanen (Rahman et al. 2008), akan tetapi Haggag dan Singer (2013) melaporkan C. capsici dapat menyebabkan antraknosa sebelum dan sesudah pascapanen. Antraknosa dapat menyerang batang, tangkai, dan buah papaya di pertanaman berdasarkan pengamatan di berbagai daerah di Indonesia. Bahkan dari hasil pengamatan di lahan, buah yang masih hijau juga sudah mulai terserang, terutama pada kultivar pepaya tipe ukuran medium (1-2 kg). Oleh karena itu penelitian ini dilakukan untuk mengoleksi spesies Colletotrichum pada berbagai bagian tanaman pepaya dan mengidentifikasinya berdasarkan pada ciri morfologi, molekuler, dan respons suhu. Pengetahuan dasar ini diharapkan berguna dalam menyusun strategi pengendalian penyakit antraknosa pada pepaya.

\section{BAHAN DAN METODE}

\section{Isolasi Colletotrichum spp.}

Cendawan diisolasi dari batang, tangkai, dan buah pepaya yang menunjukkan gejala khas antraknosa. Buah pepaya tersebut berasal dari kebun percobaan Pusat Kajian Hortikultura Tropika Pasir Kuda, Bogor dan kebun pepaya milik petani di Desa Tambak Mulyo, Kabupaten Kebumen, Jawa Tengah. Isolasi cendawan dilakukan dengan menanam jaringan tanaman pada medium agar-agar dekstrosa kentang (ADK) dan diinkubasi pada suhu $28{ }^{\circ} \mathrm{C}$. Cendawan yang tumbuh dengan ciri-ciri sebagai cendawan Colletotrichum dimurnikan mengikuti metode yang dikemukakan oleh Choi et al. (1999).

\section{Identifikasi Morfologi}

Colletotrichum diidentifikasi mengikuti Watanabe (2002), serta pustaka acuan lainnya, yaitu Smith dan Black (1990), Zakaria dan Bailey (2000), Photita et al. (2005), dan Weir et al. (2012). Pengamatan dilakukan terhadap warna koloni, pembentukan seta, dan bentuk konidium.

\section{Identifikasi Molekuler Colletotrichum spp.}

Isolasi DNA Total. Sebanyak 3 potong (diameter $\pm 5 \mathrm{~mm}$ ) biakan Colletotrichum spp. berumur 10 hari dibiakkan ke dalam erlenmeyer berisi $100 \mathrm{~mL}$ potato dextrose broth (PDB) dan diinkubasikan selama 7 hari pada suhu kamar. Miselium cendawan dipanen dengan filtrasi vakum dan dicuci menggunakan akuades steril, selanjutnya dikeringkan. DNA diekstraksi dan dimurnikan menurut metode Sambrook et al. (1989) yang dimodifikasi pada tahap ekstraksi DNA, yaitu suhu dan waktu pemanasannya. Sebanyak $0.2 \mathrm{~g}$ miselium cendawan digerus dengan nitrogen cair hingga menjadi serbuk lalu dimasukkan ke dalam tabung eppendorf, selanjutnya ditambahi $1 \mathrm{~mL}$ bufer ekstrak dan $10 \mu \mathrm{L}$ $\beta$-mercapto ethanol dan dicampur hingga homogen menggunakan vorteks. Pemanasan dilakukan untuk menghancurkan dinding sel di dalam penangas air dengan suhu $65^{\circ} \mathrm{C}$ selama 30 menit dan didinginkan sampai mencapai suhu ruang. Sebanyak $750 \mu \mathrm{L}$ kloroform isoamilalkohol (24:1) ditambahkan ke dalam tabung dan dicampur hingga homogen lalu disentrifugasi pada kecepatan $11000 \mathrm{rpm}$ selama 10 menit. Supernatan yang diperoleh dipindahkan ke tabung eppendorf baru dengan menambahkan $1000 \mu \mathrm{L}$ kloroform dicampur hingga homogen dengan vorteks dan disentrifugasi kembali pada $11000 \mathrm{rpm}$ selama 10 menit.

Supernatan dipindahkan ke tabung eppendof yang baru dan ditambahkan $1000 \mu \mathrm{L}$ isopropanol dingin. Tabung dikocok perlahan untuk mengikat DNA dan diinkubasi pada suhu $-20{ }^{\circ} \mathrm{C}$ selama 30 menit. Benang DNA yang diperoleh disentrifugasi selama 10 menit hingga mengendap. Supernatan dibuang 
dan pelet dicuci dengan etanol 70\% lalu disentrifugasi pada $11000 \mathrm{rpm}$ selama 10 menit. Etanol dibuang dan pelet dikeringvakumkan. Pelet diresuspensi dalam $100 \mu \mathrm{L}$ bufer TE dan disimpan pada suhu $-20{ }^{\circ} \mathrm{C}$ untuk digunakan dalam proses amplifikasi DNA.

Amplifikasi DNA. Proses amplifikasi dilakukan pada mesin Thermo Cycle PCR Gene Amp PCR System 9700 versi 3.12. Amplifikasi menggunakan primer universal untuk spesies Colletotrichum, yaitu forward primer ITS1 (5'-TCCGTAGGTGAACCTGCGG-3') dan reverse primer ITS4 (5'-TCCTCCGCTTAT TGATATGC-3') dengan ukuran target hasil amplifikasi ialah $580 \mathrm{pb}$. Reaksi amplifikasi DNA dengan volume total $25 \mu \mathrm{L}$ terdiri atas $2 \mu \mathrm{L}$ DNA, $2.5 \mu \mathrm{L}$ bufer $10 \mathrm{x}$ dan $\mathrm{Mg}^{2+}, 0.5 \mu \mathrm{L}$ dNTP $10 \mathrm{mM}, 1 \mu \mathrm{L}$ masing-masing primer, $0.2 \mu \mathrm{L}$ Taq DNA $\left(5\right.$ unit $\left.\mu \mathrm{L}^{-1}\right)$, dan $17.8 \mu \mathrm{LH}_{2} \mathrm{O}$. Kondisi amplifikasi dibagi menjadi beberapa tahap, yaitu pradenaturasi suhu $95{ }^{\circ} \mathrm{C}$ selama 1 menit, diikuti 30 siklus amplifikasi yang masing-masing siklus terdiri atas pemisahan utas DNA pada suhu $94{ }^{\circ} \mathrm{C}$ selama 1 menit, penempelan primer pada suhu $58{ }^{\circ} \mathrm{C}$ selama 1 menit, sintesis DNA pada suhu $72{ }^{\circ} \mathrm{C}$ selama 1 menit dan penyambungan DNA pada suhu $72{ }^{\circ} \mathrm{C}$ selama 7 menit (White et al. 1990).

Elektroforesis DNA. Produk hasil amplifikasi dianalisis menggunakan gel agarosa $1 \% \quad(0.5 \mathrm{x} \quad$ Tris-Borate EDTA/ TBE). Elektroforesis dilakukan pada 50 volt selama 50 menit dan selanjutnya gel agarosa direndam dalam larutan pewarna yang berisi etidium bromida (1\%) selama 15 menit, lalu dicuci dengan $\mathrm{H}_{2} \mathrm{O}$ selama 10 menit. Hasil elektroforesis divisualisasikan dengan transilluminator ultraviolet (APOLLO portable light box: model LB101, 1 lamp unit, 110 volts $60 \mathrm{hz}$,). Fragmen DNA yang terbentuk pada hasil elektroforesis didokumentasi.

Analisis Runutan DNA Colletotrichum spp. Produk amplifikasi dikirim ke First Base (Malaysia) untuk perunutan nukleotida. Hasil perunutan dianalisis menggunakan program basic local alignment search tool (BLAST) dengan program optimasi untuk memperoleh urutan basa DNA yang memiliki homologi dengan sikuen DNA yang terdapat dalam situs national center for biotechnology information (NCBI). Runutan nukleotida yang diperoleh dianalisis menggunakan penyejajaran berganda ClustalW pada perangkat lunak Bioedit sequence alignment editor versi 7.1.3. Hubungan kekerabatan antarisolat dikonstruksi menggunakan perangkat lunak molecular evolutionery genetic analysis versi 6.06 (MEGA6) dengan bootstrap 1000 kali ulangan.

Amplifikasi dengan Primer Spesifik. Sebanyak 8 isolat Colletotrichum yang mewakili warna koloni dan bagian tanaman yang diisolasi dilakukan amplifikasi menggunakan primer spesifik CaInt2/ITS4 dan CcInt/ITS4, masing-masing untuk mengidentifikasi C. acutatum dan C. capsici. Penggunaan primer spesifik CaInt2/ITS4 dilakukan untuk memastikan beberapa isolat dari beberapa tipe morfologi yang ditemukan dalam penelitian ini dan diduga sebagai C. gloeosporioides berdasarkan karakter morfologi, tetapi bentuk konidianya sering mirip dengan $C$. acutatum. Sementara itu penggunaan primer spesifik CcInt/ITS4 untuk memastikan bentuk konidia isolat yang berbentuk melengkung sebagai $C$. capsici.

\section{Respons Suhu Colletotrichum spp. asal Berbagai Bagian Tanaman}

Percobaan ini dilakukan mengikuti metode Smith dan Black (1990) untuk membedakan beberapa spesies Colletotrichum berdasar respons suhu terhadap pertumbuhan radialnya pada medium buatan. Biakan Colletotrichum spp. dengan diameter $5 \mathrm{~mm}$ diletakkan pada medium ADK dan diinkubasi pada suhu 16, 24, dan $32{ }^{\circ} \mathrm{C}$. Percobaan disusun dalam rancangan acak lengkap faktorial dengan 2 faktor, yaitu biakan Colletotrichum spp. dan suhu. Diameter koloni pertumbuhan cendawan diamati pada hari ke-10 setelah inkubasi.

\section{HASIL}

\section{Identifikasi secara Morfologi}

Sebanyak 20 isolat diperoleh dari beberapa bagian tanaman yang menunjukkan gejala antraknosa. Seluruhnya merupakan 
Colletotrichum spp. Berdasarkan pada karakter morfologi, Colletotrichum yang ditemukan dalam penelitian ini secara umum dibagi menjadi 3 kelompok tipe morfologi (Gambar 1). Kelompok I, warna koloni tampak atas yang bervariasi mulai abu-abu, krem, atau hijau tua dengan koloni tampak bawah abuabu; aservulus berwarna oranye yang berisi massa konidia terlihat jelas pada pusat koloni; konidium silinder dengan kedua ujungnya membulat, membentuk 2 gelembung minyak; dan seta tidak ada, baik pada medium maupun pada jaringan tanaman. Kelompok II, warna koloni seragam, yaitu tampak atas berwarna abu-abu dan tampak bawah berwarna abu-abu kehitaman; konidium silinder dengan ujung membulat, tidak membentuk gelembung minyak; seta tidak ada, baik pada medium maupun jaringan tanaman inang. Tipe morfologi kelompok III ialah warna koloni tampak atas krem atau abu-abu, dengan warna koloni tampak bawah cokelat dengan cincin konsentris, konidium melengkung dengan kedua ujung meruncing dan membentuk 2 gelembung minyak; seta dihasilkan hanya pada medium ADK (Gambar 2).

Colletotrichum tipe morfologi kelompok I ditemukan pada semua bagian tanaman (batang: BT1, BT14, BT1, BT16; buah: B17, B24, B24, B50; dan tangkai daun: TP, T2, T3, T20). Tipe morfologi kelompok II ditemukan pada bagian batang dan tangkai daun (batang: B17; tangkai daun: T15, T21, T26), dan kelompok III hanya ditemukan pada bagian buah (B4, B7, B8, dan B19). Jika hanya didasarkan pada warna koloni dan bentuk konidium, kelompok I dan II (16 galur) diidentifikasi sebagai C. gloeosporioides sensu lato. Meskipun bentuk konidia pada kelompok I dan II sama, akan tetapi pada kelompok II konidianya tidak membentuk gelembung minyak. Dengan adanya perbedaan ini, salah satu galur yang mewakili tipe morfologi kelompok II (T15) diuji lebih lanjut secara molekuler dengan primer universal untuk memastikan spesiesnya. Isolat-isolat dari tipe morfologi III dengan bentuk konidia melengkung dengan kedua ujung meruncing yang oleh beberapa peneliti (Haggag dan
Singer 2013; Rahman et al. 2008; Sato et al. 2015) diidentifikasi secara morfologi sebagai C. capsici, diidentifikasi lebih lanjut secara molekuler untuk lebih memastikan spesiesnya seperti yang disarankan oleh Cannon et al. (2012).

\section{Identifikasi Molekuler Colletotrichum spp.}

Amplifikasi DNA. Sebanyak 8 galur yang mewakili bagian tanaman dan tipe morfologi, yaitu BT 15 dan BT16 (tipe I dari batang), T15 dan T26 (tipe II dari tangkai daun), serta B4, B7, B8, dan B9 (tipe III dari buah) tidak teramplifikasi fragmen DNA-nya, baik dengan primer spesifik C. acutatum maupun C. capsici. Dengan hasil tersebut, ketiga kelompok tipe morfologi Colletotrichum yang ditemukan bukan spesies $C$. acutatum maupun $C$. capsici. Akan tetapi 5 dari 8 galur yang diuji, yaitu T15 (tipe morfologi II), B4, B7, B8, dan B19 (tipe morfologi III) berhasil diamplifikasi dengan ukuran $\pm 600 \mathrm{pb}$ menggunakan primer universal ITS1/ITS4 (Gambar 3). Berdasarkan hasil sikuensing, 4 galur (B4, B7, B8 dan B9) dinyatakan sebagai $C$. truncatum, dan 1 galur (T15) dinyatakan sebagai C. magnum.

Filogenetika Colletotrichum dari bagian pepaya. Berdasarkan analisis filogenetika yang disejajarkan dengan database di NCBI galur $C$. truncatum dari hasil penelitian ini memiliki kekerabatan yang lebih dekat dengan galur dari Malaysia dibandingkan dengan galur yang berasal dari negara Asia lainnya (China, Taiwan dan Thailand). Sementara itu C. magnum yang diisolasi dari tangkai daun (T15) berkerabat dekat dengan galur yang berasal dari Brazil (Gambar 4).

Respons Pertumbuhan Colletotrichum spp. terhadap Suhu. Pertumbuhan koloni (diameter) Colletotrichum yang diisolasi dari tanaman pepaya dipengaruhi oleh suhu dan spesiesnya. Dari uji statistik, baik spesies maupun suhu secara tunggal dan interaksinya menunjukkan perbedaan yang nyata. Ketiga spesies yang diuji, C. gloesporioides, $C$. magnum, dan $C$. truncatum, secara umum tumbuh optimum pada suhu $24^{\circ} \mathrm{C}$. Pada suhu $16{ }^{\circ} \mathrm{C}, \mathrm{C}$. gloeosporioides cenderung tumbuh lebih cepat dibandingkan 2 spesies lainnya, 

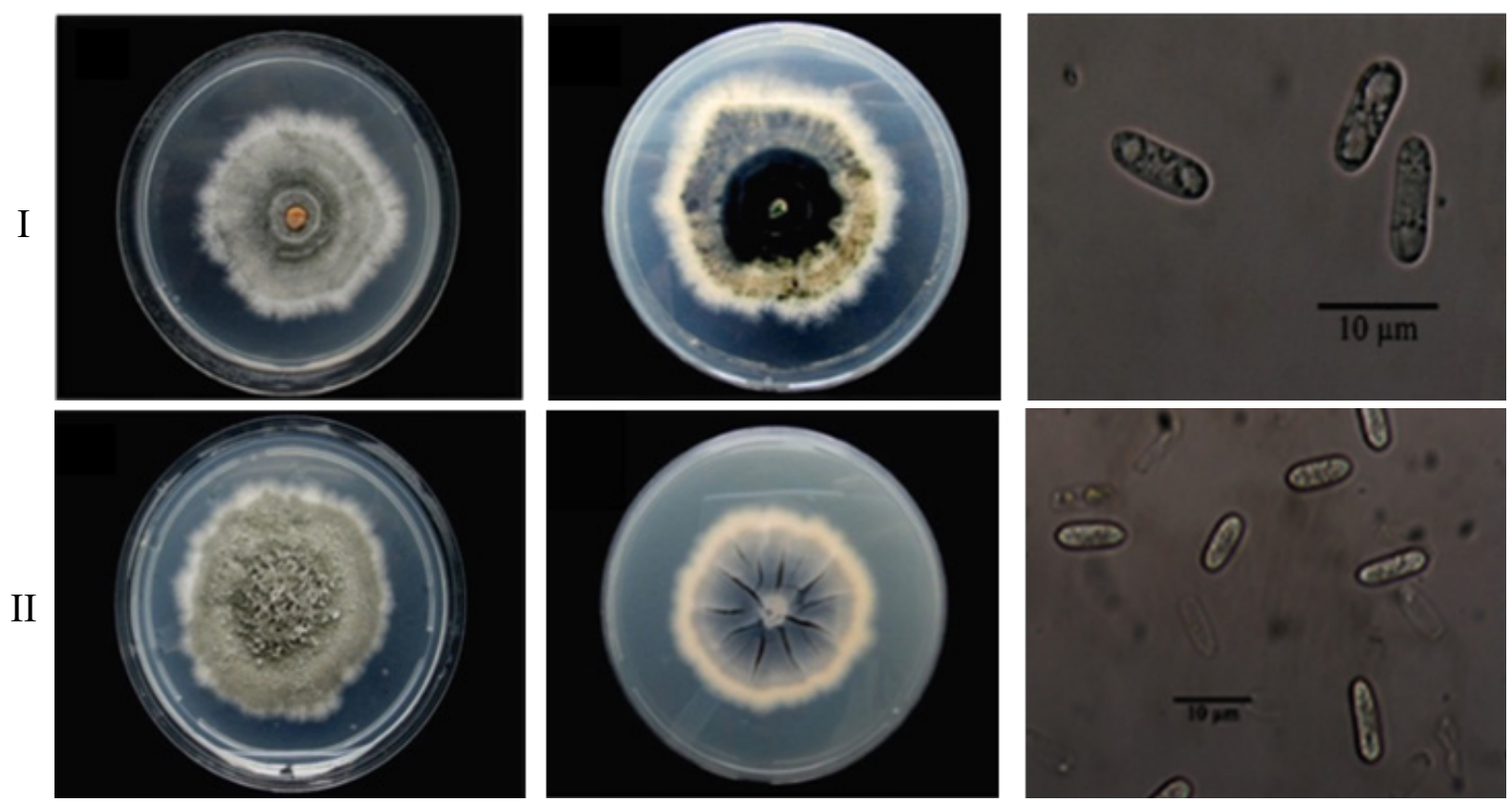

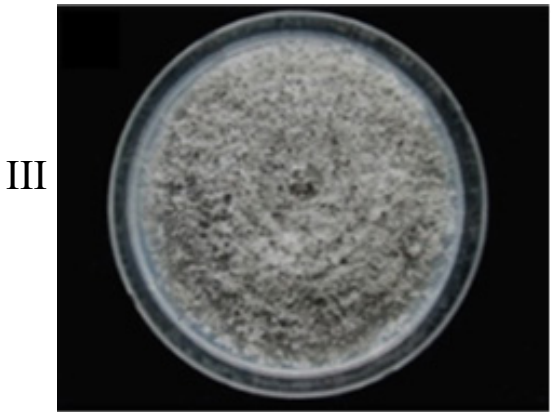

Tampak atas

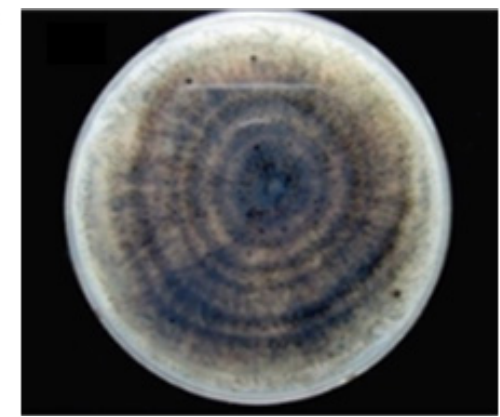

Tampak bawah

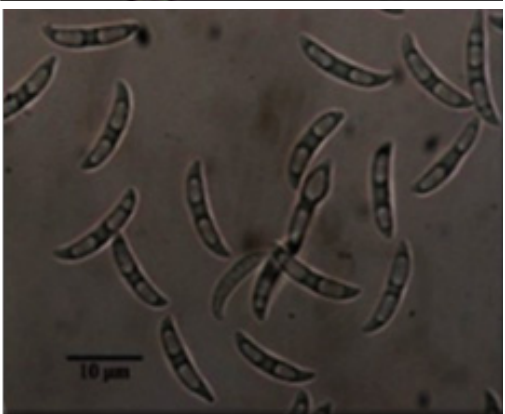

Bentuk konidium

Gambar 1 Karakter morfologi Colletotrichum spp. kelompok I, II, dan III asal pepaya pada medium agar-agar dekstrosa kentang.

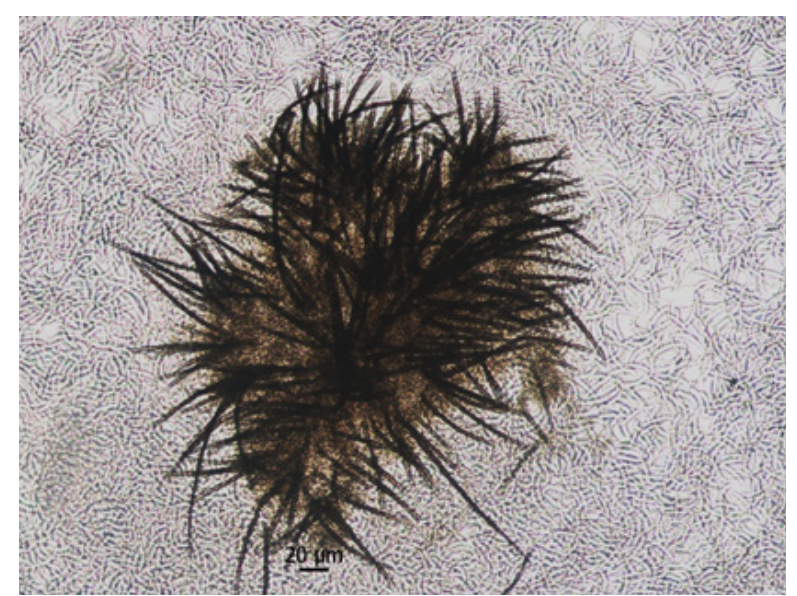

Gambar 2 Seta yang terbentuk oleh Colletotrichum isolat kelompok ke-III pada medium agar-agar dekstrosa kentang.

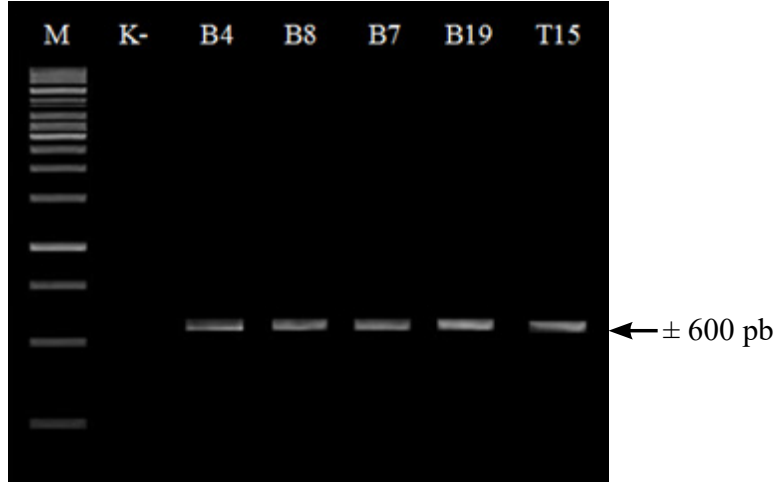

Gambar 3 Amplifikasi DNA 5 isolat Colletotrichum spp. asal pepaya, menggunakan pasangan primer universal ITS1/ITS4. M, Penanda DNA 1 kb ladder; K-, Kontrol negatif; B4, B8, B7, B19, Isolat asal buah dan; $\mathrm{T} 15$, isolat asal tangkai. 


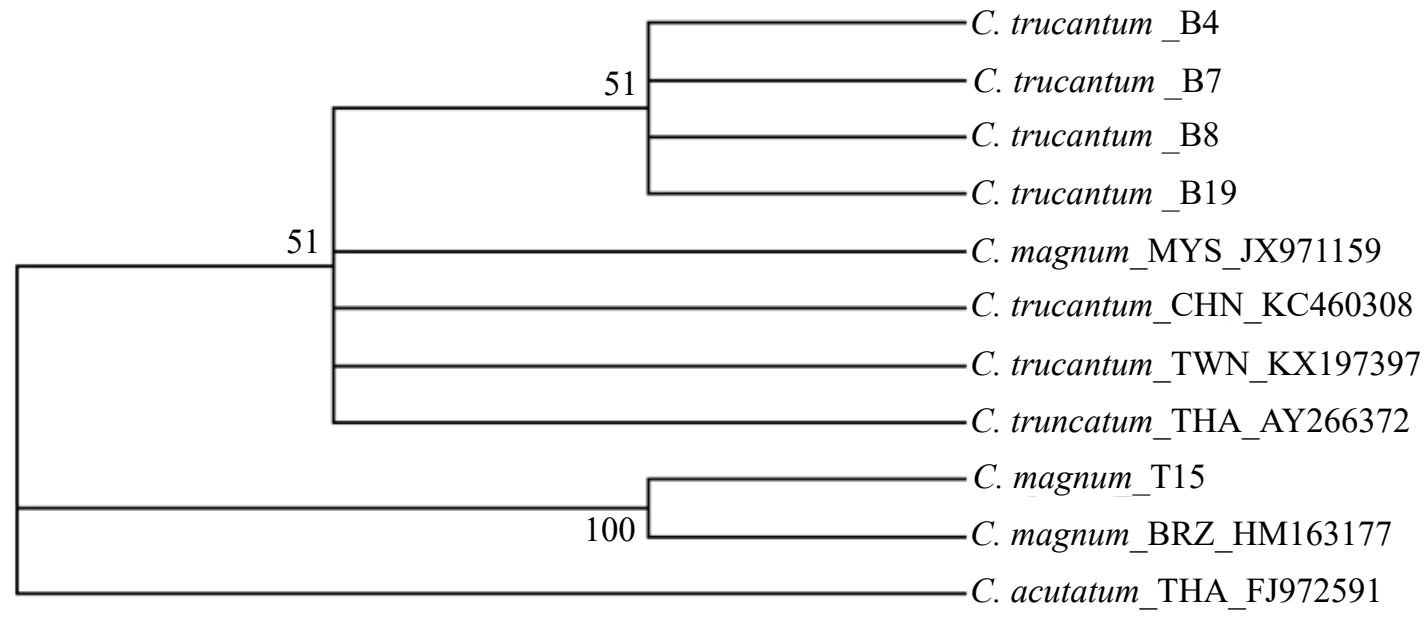

Gambar 4 Pohon filogenetika spesies Colletotrichum spp. yang berasal dari buah dan tangkai pepaya di Kebumen, Indonesia. C. acutatum_THA_FJ972591 digunakan sebagai pembanding di luar group.

sementara itu pada suhu $32{ }^{\circ} \mathrm{C}$ C. truncatum tumbuh paling cepat dibandingkan dengan lainnya (Gambar 5).

\section{PEMBAHASAN}

Gejala awal antraknosa pada buah yang disebabkan oleh C. gloeosporioides ditandai dengan bercak oval, sedikit berair, membentuk lesio cekung pada permukaan buah yang akan berkembang menjadi nekrosis, dan kematian pada jaringan (Patel et al. 2005). Selama ini Colletotrichum sebagai penyebab penyakit antraknosa pada pepaya lebih dikenal sebagai penyakit pascapanen, akan tetapi proses infeksinya sudah dimulai sejak di pertanaman dan bersifat laten (Maeda dan Nelson 2014). Hasil survei lapangan menunjukkan bahwa akhir-akhir ini mulai banyak muncul gejala penyakit di pertanaman pepaya di sebagian wilayah Indonesia. Gejala penyakit antraknosa tersebut ditemukan selain pada bagian buah, juga terjadi pada tangkai daun dan batang. Berdasakan pustaka standar (Semangun 2007) serangan patogen ini pada bagian buah hanya terjadi ketika buah menjelang matang di lapangan dan diteruskan sampai pascapanen, akan tetapi dari hasil penelitian ini menunjukkan bahwa cendawan tersebut juga ditemukan menyerang pada buah yang masih hijau. Selain di Indonesia, peneliti lain sudah pernah melaporkan adanya infeksi antraknosa di lapangan, tetapi hanya melaporkan kejadiannya pada buah (Haggag dan Singer 2013).

Hasil identifikasi secara morfologi dan/ atau molekuler ditentukan tiga spesies Colletotrichum pada pepaya di pertanaman, yaitu $C$. gloeosporioides, C. magnum, dan $C$. truncatum. Berdasarkan warna koloni yang bervariasi, Colletotrichum dalam kelompok I ini diidentifikasi sebagai $C$. gloesporioides seperti yang dikemukakan oleh Rampersad (2011). Tipe morfologi kelompok I yang dicirikan dengan koloni berwarna abuabu sampai abu-abu kehijauan (olive) dan terbentuknya aservulus dengan massa konidia berwarna oranye juga dikuatkan oleh peneliti lain sebagai $C$. gloeosporioides (MolinaChaves et al. 2017; Torres-Calzada et al. 2013). Mengingat $C$. gloeosporioides oleh Weir et al. (2012) diketahui sebagai kompleks spesies (species complex), maka Colletotrichum tipe morfologi I yang dalam penelitian ini baru diidentifikasi secara morfologi masih perlu diklarifikasi lebih lanjut secara molekuler. Kelompok morfologi III dengan konidium melengkung (kurva) dan ujung meruncing pernah dilaporkan di Mesir (Haggag dan Singer 2013) dan Malaysia (Rahman et al. 2008) pada pepaya pascapanen. Kedua laporan tersebut berhasil mengidentifikasi Colletotrichum dengan tipe konidia ini sebagai C. capsici. Akan tetapi di dalam penelitian 
A

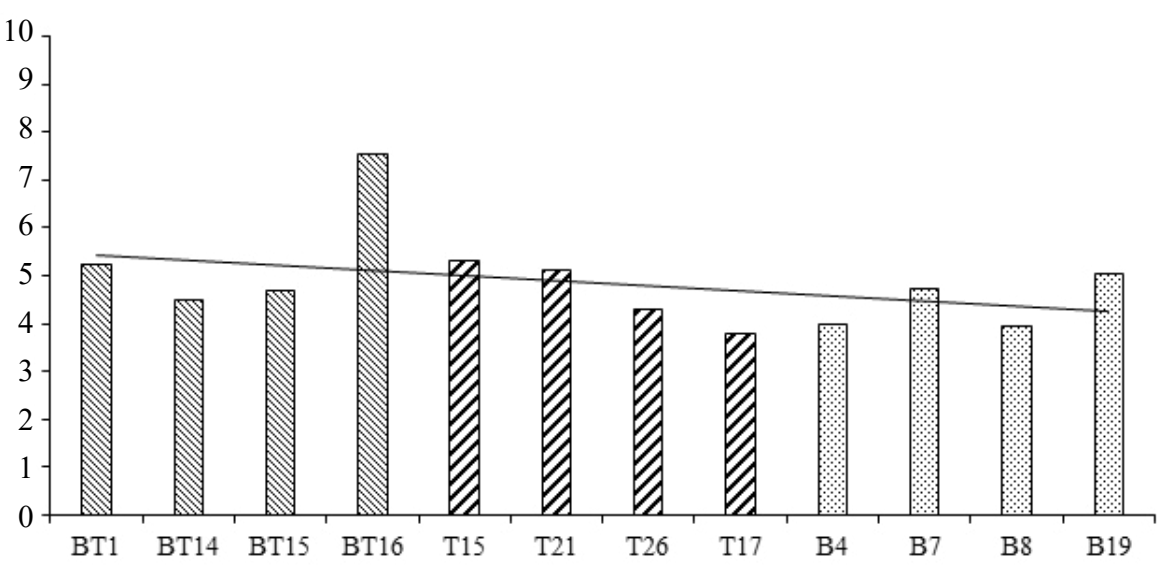

B
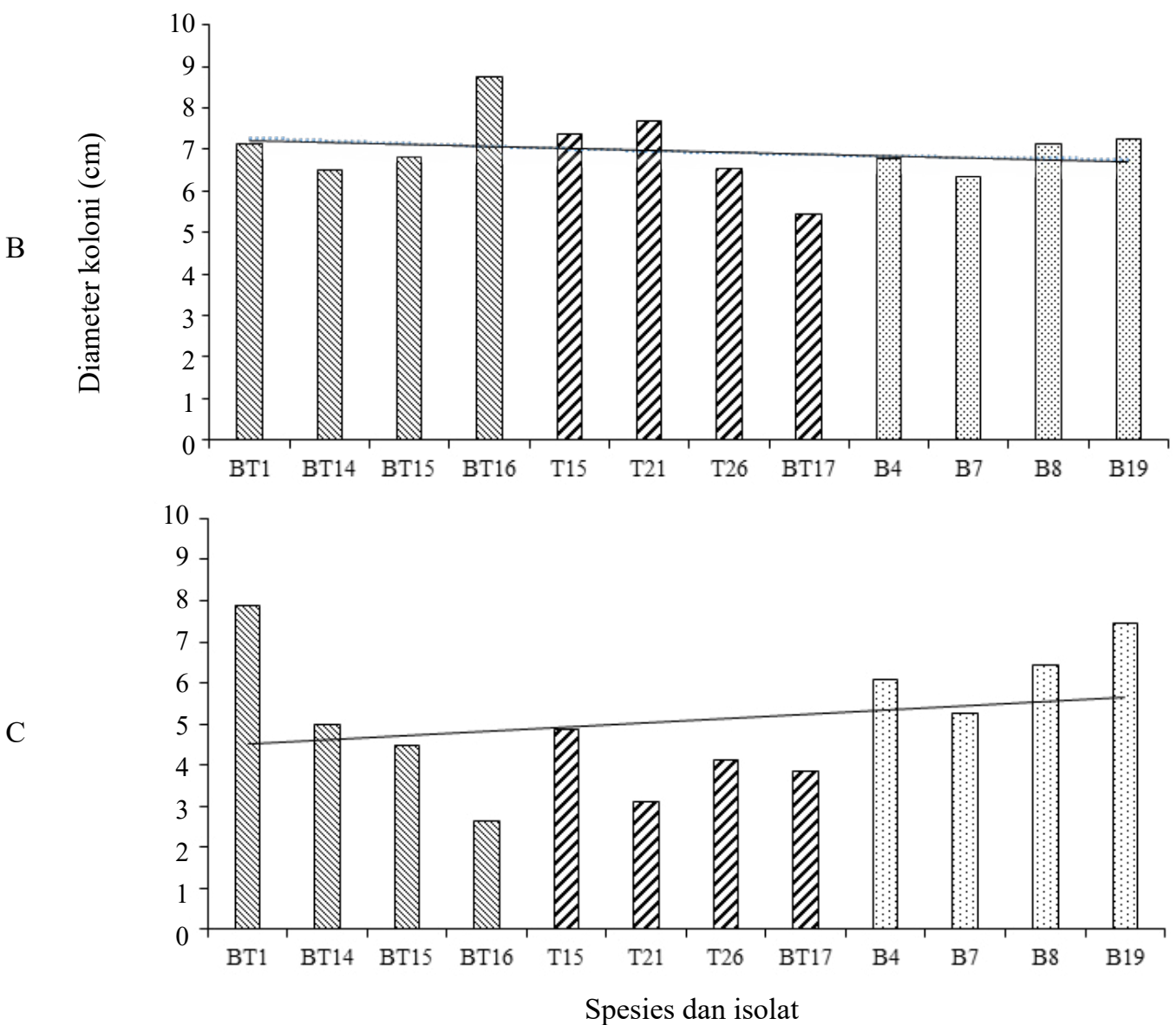

Gambar 5 Respons pertumbuhan beberapa spesies Colletotrichum pada medium agar-agar dekstrosa kentang pada tiga tingkat suhu inkubasi. A, Suhu $16^{\circ} \mathrm{C}$; B, Suhu $24^{\circ} \mathrm{C}$; C, Suhu $32^{\circ} \mathrm{C}$. $\mathbb{N}$, C. gloeosporioides; $\boldsymbol{\nabla}$, C. magnum; $: \cdot ;$, C. truncatum.

ini, galur Colletottrichum dengan tipe konidia seperti tersebut ternyata tidak teramplifikasi dengan primer spesifik CcInt/ITS4 untuk $C$. capsici. Berdasarkan hasil sikuensing spesies ini diidentifikasi sebagai $C$. truncatum. Spesies ini juga pernah dilaporkan menyerang pertanaman pepaya di Trinidad (Rampersad 2011) dan Costa Rica (Molina-Chaves et al. 2017). Sampai saat ini C. gloeosporioides paling sering dilaporkan menyerang pada pepaya pascapanen di Indonesia (Semangun 2007) dan di negara lain (Rahman et al. 2008). Dari ketiga spesies yang berhasil diidentifikasi tersebut, $C$. magnum (dari tangkai) dan $C$. truncatum (dari buah pepaya) merupakan laporan pertama di Indonesia.

C. magnum cenderung memiliki warna koloni yang seragam, yaitu abu-abu (tampak 
atas) dan abu-abu kehitamaan (tampak bawah). Dari bentuk konidium, C. gloeosporioides dan $C$. magnum memiliki bentuk yang sama, yaitu silinder dengan kedua ujung membulat. Keduanya dapat dibedakan dari ada tidaknya gelembung minyak pada konidium. $C$. truncatum yang ditemukan dalam penelitian ini mudah dibedakan dari dua spesies lainnya. Koloni spesies ini membentuk cincin konsentris, konidium melengkung dan membentuk seta pada medium ADK.

Colletotrichum yang diisolasi dari buah, tangkai daun dan batang di lapangan ialah $C$. truncatum, C. magnum dan C. gloeosporioides. Dari penelitian ini, $C$. truncatum hanya ditemukan di lapangan pada bagian buah, sedangkan C. magnum sebagian besar (3 dari 4 isolat) ditemukan pada tangkai daun. Sementara itu C. gloeosporioides merupakan spesies yang dominan dan ditemukan pada semua bagian tanaman. Berdasarkan hasil identifikasi molekuler, isolat asal buah dengan konidium melengkung (isolat kelompok III) menunjukkan hubungan kekerabatan yang paling dekat dengan spesies $C$. truncatum asal Malaysia, sedangkan salah satu galur (T15) asal tangkai dengan konidium silindris dan tanpa gelembung minyak (tipe morfologi II) yang diperoleh dalam penelitian ini memiliki hubungan kekerabatan dengan $C$. magnum asal Brazil. Keberadaan C. magnum sebagai patogen antraknosa pada tanaman pepaya juga pernah dilaporkan oleh peneliti lain di Meksiko (Tapia-Tussell et al. 2016) dan Costarica (Molina-Chaves et al. 2017).

Dari percobaan pengaruh suhu, pertumbuhan Colletotrichum asal pepaya dipengaruhi oleh spesies dan suhu. Secara umum, ketiga spesies Colletotrichum tumbuh optimumpada suhu $24^{\circ} \mathrm{C}$ dan relatifsama, tetapi menunjukkan perbedaan ketika ditumbuhkan pada suhu yang lebih rendah $\left(16{ }^{\circ} \mathrm{C}\right)$ dan suhu lebih tinggi $\left(32{ }^{\circ} \mathrm{C}\right)$. Pada suhu yang lebih rendah $\left(16^{\circ} \mathrm{C}\right), \mathrm{C}$. gloesporioides cenderung tumbuh lebih cepat dibandingkan dua spesies lainnya. Sementara itu C. truncatum tumbuh lebih cepat pada suhu yang lebih tinggi $\left(32{ }^{\circ} \mathrm{C}\right)$ dibandingkan dua speseis lainnya. Sangeetha dan Rawal (2010) melaporkan bahwa konidium C. gloeosporioides belum mampu berkecambah pada suhu $15-20{ }^{\circ} \mathrm{C}$ dan $30{ }^{\circ} \mathrm{C}$. Penelitian Smith dan Black (1990) juga menunjukkan adanya perbedaan respons pertumbuhan koloni tiga spesies Colletotrichum pada stroberi terhadap suhu, dimana salah satu spesies tumbuh lebih lambat dibandingkan dua spesies lainnya pada semua kisaran suhu yang diujikan. Dengan demikian, perbedaan respons pertumbuhan koloni terhadap suhu dapat digunakan sebagai salah satu faktor dalam membedakan tiga spesies Colletotrichum pada tanaman pepaya.

\section{UCAPAN TERIMA KASIH}

Penghargaan dan terima kasih disampaikan kepada Lembaga Pengelola Dana Pendidikan (LPDP), Kementerian Keuangan Republik Indonesia melalui Beasiswa Tesis Batch II Tahun 2016.

\section{DAFTAR PUSTAKA}

Cannon PF, Damm U, Johnston PR, Weir BS. 2012. Colletotrichum-current status and future directions. Stud Mycol. 73:181-213. DOI: https://doi.org/10.3114/sim0014.

Choi YW, Hyde KD, Ho WH. 1999. Single spore isolation of fungi. Fungal Divers. 3:29-38. Haggag WM, Singer S. 2013. First report of Colletotrichum capsici causing pre and postharvest anthracnose on papaya in Egypt. Int $\mathbf{J}$ Engineer Innov Technol. 3(6):151-152.

Maeda C, Nelson S. 2014. Anthracnose of papaya in Hawai'i. Mãnoa (US): College of Tropical Agriculture and Human Resources, University of Hawai'i.

Molina-Chaves A, Gómez-Alpizar L, UmañaRojas G. 2017. Identificación de especies del género Colletotrichum asociadas a la antracnosis en papaya (Carica papaya L.) en Costa Rica. Agronomía Costarricense 41(1): 69-80. DOI: https:// doi.org/10.15517/rac.v41i1.29752.

Patel RV, Joshi KR, Solanky KU, Sabalpara AN. 2005. Colletotrichum gloeosporioides: 
a new leaf spot pathogen of turmeric in Gujarat. Ind J Phytopathol. 58 (1):125.

Photita W, Taylor PWJ, Ford R, Hyde KD, Lumyong S. 2005. Morphological and molecular characterization of Colletotrichum species from herbaceous plants in Thailand. Fungal Divers. 18:117133.

Rahman MA, Mahmud TMM, Kadir J, Abdul Rahman R, Begum MM. 2008. Major postharvest fungal diseases of papaya cv. Sekaki in Selangor, Malaysia. Pertanika J Trop Agric Sci. 31(1):27-34.

Rampersad SN. 2011. Molecular and phenotypic characterization of Colletotrichum species associated with anthracnose disease of papaya in Trinidad. Plant Dis. (95): 1244-1254. DOI: https:// doi.org/10.1094/PDIS-02-11-0080.

Sambrook J, Fritsch EF, Maniatis T. 1989. Molecular Cloning: a Laboratory Manual. Ed ke-2. New York (US): Cold Spring Harbor.

Sangeetha CG, Rawal RD. 2010. Temperature requirement of different isolates of Colletotrichum gloeosporioides isolated from mango. Afr $\mathrm{J}$ Biotechnol. 9(21):3086-3090.

Sato T, Moriwaki I, Kaneko S. 2015. Anthracnose fungi with curved conidia Colletotrichum spp. belonging to ribosomal groups 9-13, and their host ranges in Japan. JARQ. 49(4):351-362. DOI: https://doi. org/10.6090/jarq.49.351.

Semangun H. 2007. Penyakit-penyakit Tanaman Hortikultura di Indonesia. Yogyakarta (ID): Gadjah Mada University Press.

Smith BJ, Black LL. 1990. Morphological, cultural, and pathogenic variation among
Colletotrichum species isolated from strawberry. Plant Dis. 74:69-76. DOI: https://doi.org/10.1094/PD-74-0069.

Tapia-TussellR, Cortes-VelazquezA, ValenciaYah T. 2016. First report of Colletotrichum magnum causing anthracnose in papaya in Mexico. Plant Dis. 100(11):2323. DOI: https://doi.org/10.1094/PDIS-03-16-0324PDN.

Torres-Calzada C, Tapia-Tussel R, HigueraCiapara I, Perez-Brito D. 2013. Morphological, pathological and genetic diversity of Colletotrichum species responsible for anthracnose in papaya (Carica papaya L). Eur J Plant Pathol. 135(1):67-79. DOI: https://doi. org/10.1007/s10658-012-0065-7.

Watanabe T. 2002. Pictorial Atlas of Soil and Seed Fungi Morphologies of Cultured Fungi and Key to Species. Ed ke-2. Boca Raton (US). CRC Pr. DOI: https://doi. org/10.1201/9781420040821.

Weir BS, Johnston PR, Damm U. 2012. The Colletotrichum gloeosporioides species complex. Stud Mycol. 73:115-180. DOI: https://doi.org/10.3114/sim0011.

White TJ, Bruns T, Lee S, Taylor J. 1990. Amplification and direct sequencing of fungal ribosomal RNA genes for phylogenetics. Di dalam: Innis MA, Gelfand DH, Sninsky JJ, White TJ, editor. PCR Protocols: A Guide to Methods and Applications. San Diego (US): Academic Pr. hlm 315-322. DOI: https://doi. org/10.1016/B978-0-12-372180-8.500421.

Zakaria M, Bailey JA. 2000. Morphology and cultural variation among Colletotrichum isolates obtained from tropical forest nurseries. J Trop For Sci. 12(1):1-20. 